\title{
RIVER ANTHROPIZATION: CASE STUDIES IN REGGIO CALABRIA, ITALY
}

\author{
ROSA VERSACI, FRANCESCA MINNITI, GIANDOMENICO FOTI, \\ CATERINA CANALE \& GIUSEPPINA CHIARA BARILLÀ \\ DICEAM Department. Mediterranea University of Reggio Calabria, Italy
}

\begin{abstract}
The considerable anthropic pressure that has affected most of Italian territory in the last 60 years has altered natural conditions of coasts and river, thus increasing exposure to environmental risks. For example, increase in soil waterproofing caused a reduction in hydrological losses with a rise in flood flows (with the same rainfall conditions), especially in urban areas. This issue is important in territories like Mediterranean region, that are prone to flooding events. From this point of view, recent advances in remote sensing and geographical information system (GIS) techniques allow us to analyze morphological changes occurred in river and in urban centers, in order to evaluate possible increases in environmental risks related to the anthropization process. This paper analyzes and describes the effects of anthropization process on some rivers in the southern area of the Reggio Calabria city (the Sant'Agata, Armo and Valanidi rivers). This is a heavily anthropized area due to the presence of the airport, highway and houses. The analysis was carried out using QGIS, through the comparison of cartography data of the last 60 years, which consists of aerophotogrammetry of 1955, provided by Italian Military Geographic Institute, and the latest satellite imagery provided by Google Earth Pro. Keywords: river anthropization, flooding risk, GIS, cartography data, Reggio Calabria.
\end{abstract}

\section{INTRODUCTION}

The advance in anthropogenic pressure observed in Italy over the last 60 years [1], [2] has increased vulnerability of territory under the action of natural events such as floods [3]-[5], debris flow [6], [7], storms [8], [9] and coastal erosion [10], [11]. In fact, the anthropization of the territory has enhanced the impervious surfaces and the flooding effect due to the reduction in hydrological losses and in flow resistance [12], [13] Furthermore, the anthropization rises the discharge and the runoff volume, and reduces the concentration time [14]-[16]. Moreover, the increase in anthropogenic pressure has altered the river dynamics due to the constriction of the riverbeds to build houses, roads, economic activities etc., that increasing the flooding risk, especially in urban areas [17]-[19]. This issue is important in territories like Mediterranean region, that are prone to flooding events [20]-[22]. Other important factors for alteration of river dynamics are construction of hydraulic structures, which interferes with fluvial dynamics such as levees, dams [23], [24], the inert drains from river beds, and soil erosion by water [25], [26]. Alterations of river dynamics, and therefore of river transport, has also modified coastal dynamics [27]. Indeed, shoreline position is an important factor in coastal dynamics [28]-[30] and it is related to natural and anthropogenic factors [31], [32]. The most important anthropogenic factor [33] is construction of buildings, infrastructure, ports and coastal defence works [34]-[40]. Among natural factors, the most important are the action of wave motion [41]-[45] and interaction between longshore and river transport [46]-[50]. Therefore, an accurate knowledge of river [51], [52] and coastal morphodynamics [53], [54] and of its natural and anthropogenic causes [55]-[57] are important for river and coastal zone planning and management [58], [59].

This paper analyzes and describes the effects of anthropization process on some rivers in the southern area of the Reggio Calabria city (the Sant'Agata, Armo and Valanidi rivers). The analysis was carried out using QGIS, through the comparison of cartography data of the last 
60 years, which consists of aerophotogrammetry of 1955, provided by Italian Military Geographic Institute, and the latest satellite imagery provided by Google Earth Pro.

\section{SITE DESCRIPTION}

The study area is located in the Southern part of the Reggio Calabria city (Italy) and it is characterized by the presence of both sea and mountains very close to each other and by the presence of "fiumare" (Fig. 1). These are typical rivers of southern Italy with torrential and irregular regime: in summer these fiumare are often completely dry [60]. In Reggio Calabria there are more than 10 rivers and in this paper Sant'Agata, Armo and Valanidi are analyzed (Fig. 2). The largest of these is the Sant'Agata river, whose basin has an area of over $50 \mathrm{~km}^{2}$, while Valanidi and Armo rivers have an area of 30 and $15 \mathrm{~km}^{2}$, respectively. Moreover, the final part of Valanidi river forks in two reaches. The study area is heavily anthropized due to the presence, especially, of the airport, between Sant'Agata and Armo rivers, a sports center, in the Sant'Agata river, a highway, interfering especially with Valanidi river, and various industrial activities (Figs 3 and 4).

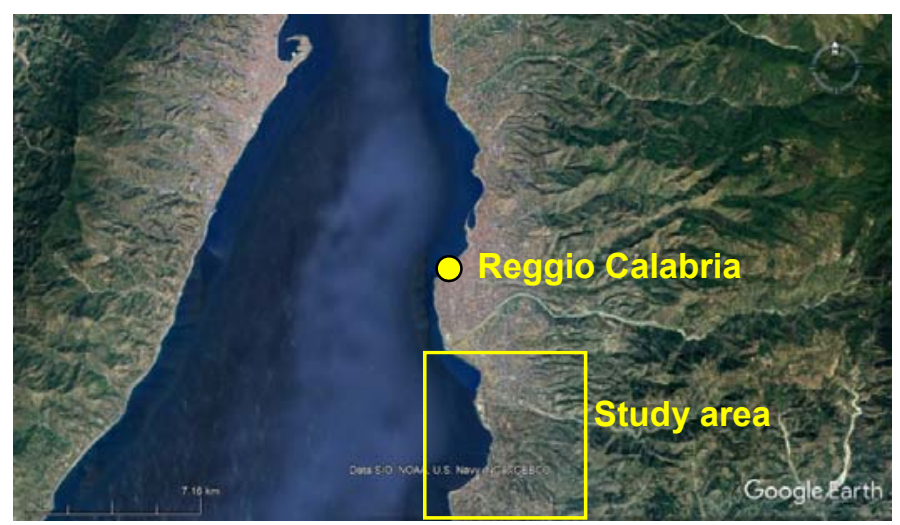

Figure 1: Study area location.

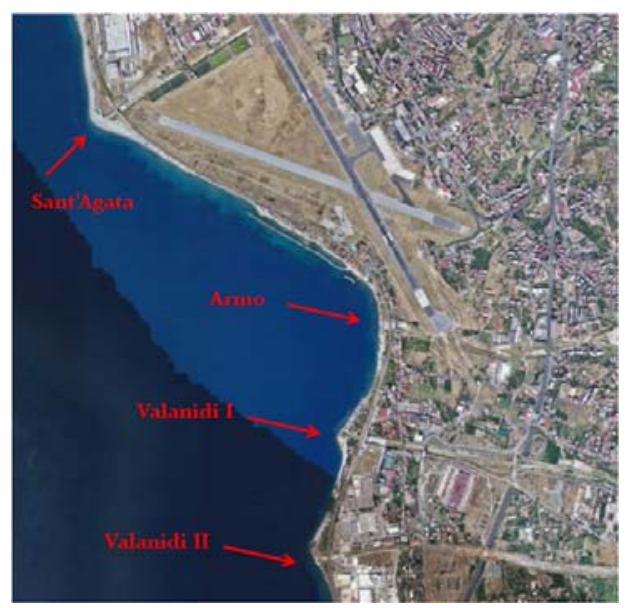

Figure 2: River present in the study area. 


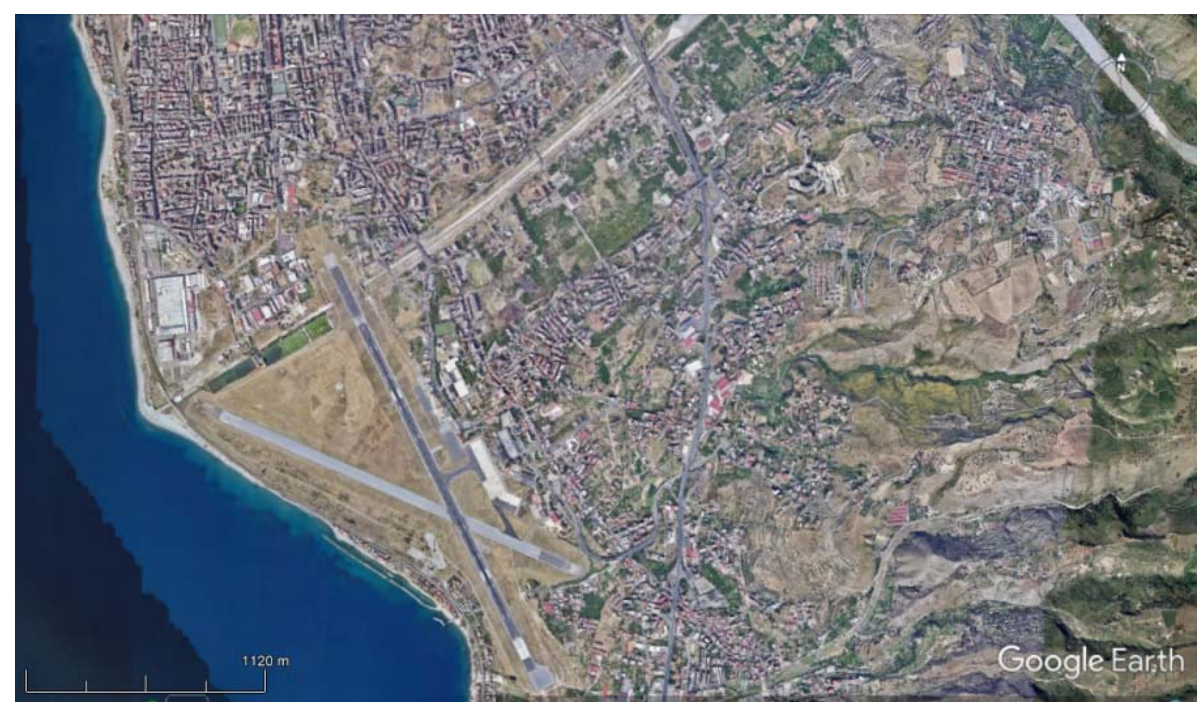

Figure 3: Detail of the Sant'Agata river.

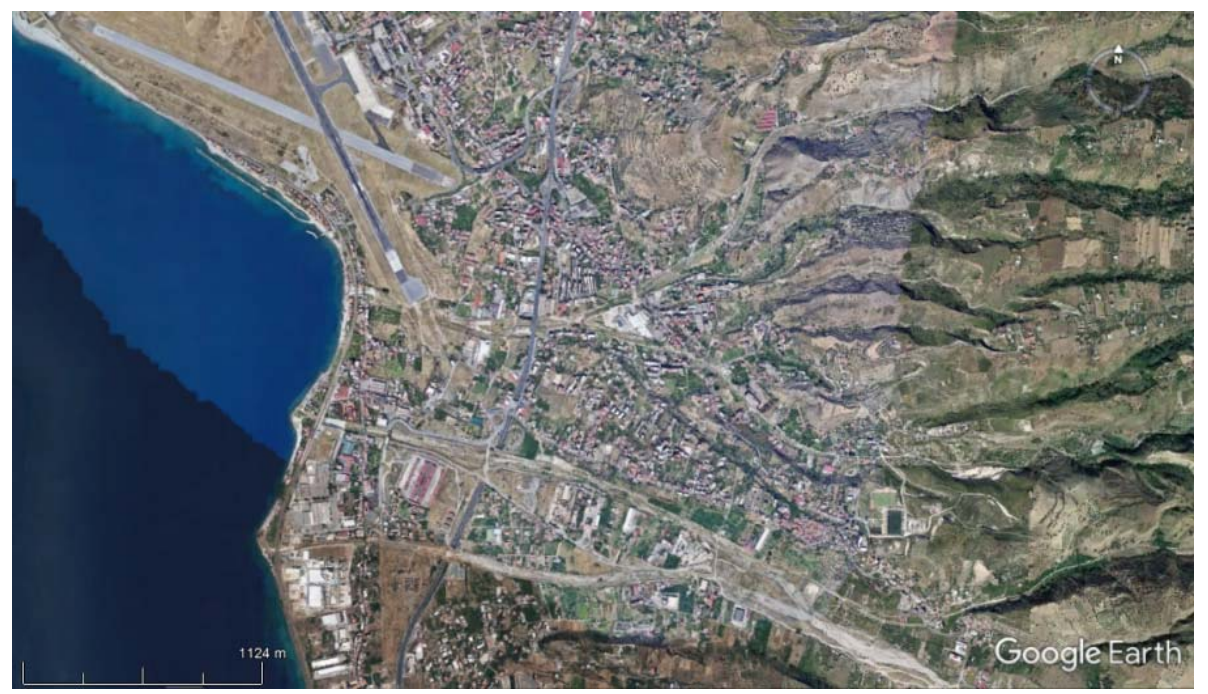

Figure 4: Detail of the Armo and Valanidi rivers.

\section{ANALYSIS OF THE ANTHROPIZATION EFFECTS}

The analysis was carried out using QGIS, through the comparison of cartography data of the last 60 years, which consists of aerophotogrammetry of 1955, provided by Italian Military Geographic Institute, and the latest satellite imagery provided by Google Earth Pro. Shapefiles were created to identify rivers, roads and buildings.

Fig. 5 shows the 1955 aerophotogrammetry of the entire study area, showing the created shapefiles, in particular are shown in blue the rivers, in red the streets and in yellow the 
buildings. Fig. 6 shows, instead, the last available satellite image, of September 2017, in which the created shapefiles were superimposed.

From the comparison of these two figures it is possible to observe how in 1955 the study area was not very anthropized, with very wide river beds, especially in the terminal parts, and with few infrastructures interfering with them. The airport had already been built, although it was partially obscured in the aerophotogrammetry, but it was entirely included between the Sant'Agata and Armo rivers without interfering with them.

At present, however, the territory is almost totally anthropized. In particular, with regard to the Sant'agata river, it is possible to observe that the final part, of a length of about $3 \mathrm{~km}$ and included between the highway and the mouth, has been restricted, from over 200 to about $20 \mathrm{~m}$, and channeled through a concrete channel. Inside the river, a sports center has built and the extension of the airport runway on the north side passes over the river itself (Fig. 7). Also the final part of Armo river has been restricted, from more than 150 to about $30 \mathrm{~m}$, and has been slightly diverted to extend the airport runway on the south side, which passes over the river as for Sant'Agata river (Fig. 8). Regarding Valanidi river, its two reaches have not undergo relevant narrowing but the highway, that connects Reggio Calabria with Taranto crossing the entire Ionian Calabria, passes below the riverbed through two tunnels (Fig. 8).

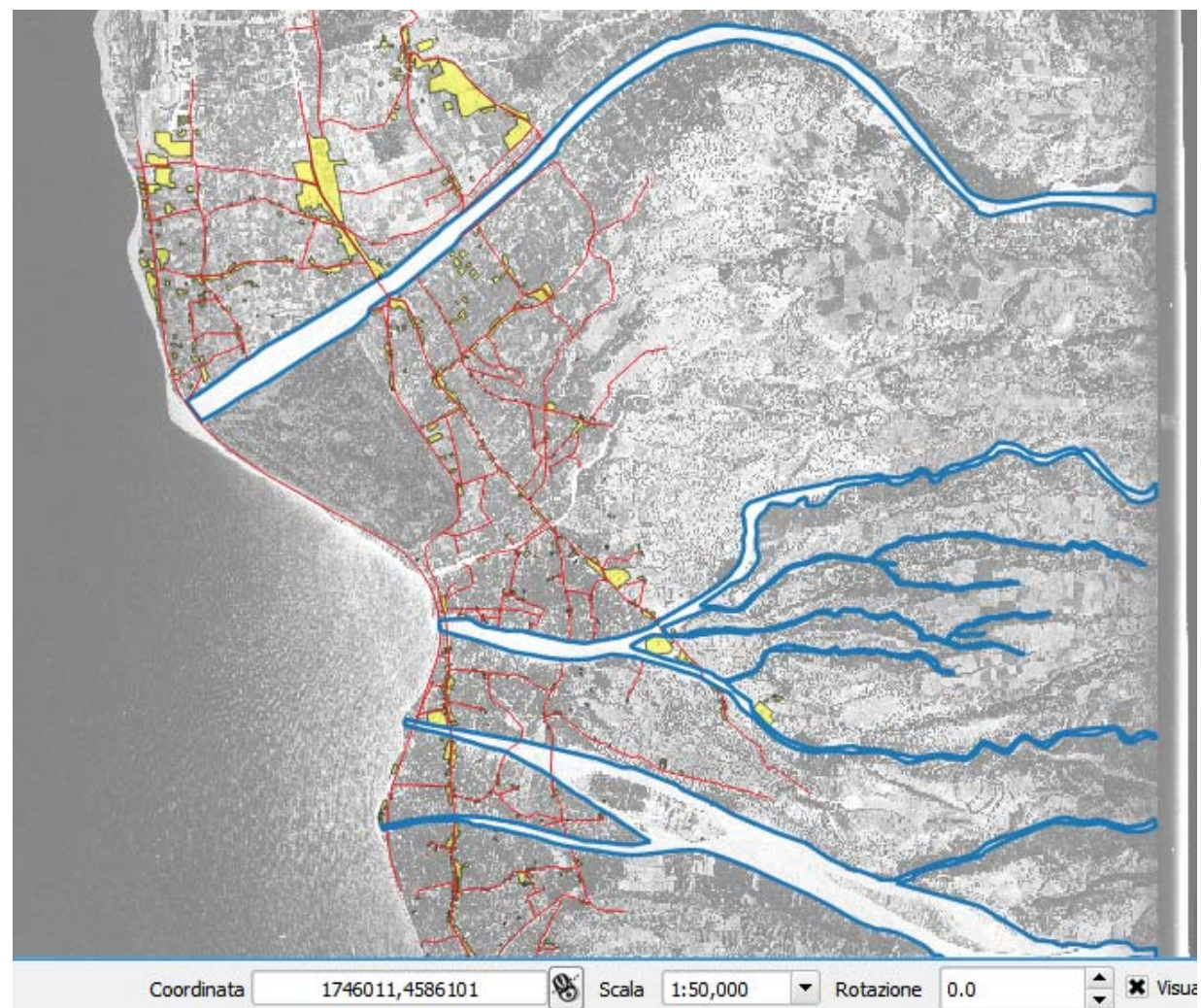

Figure 5: Aerophotogrammetry of 1955 of the study area. Legend: blue: rivers; red: roads; yellow: buildings. 


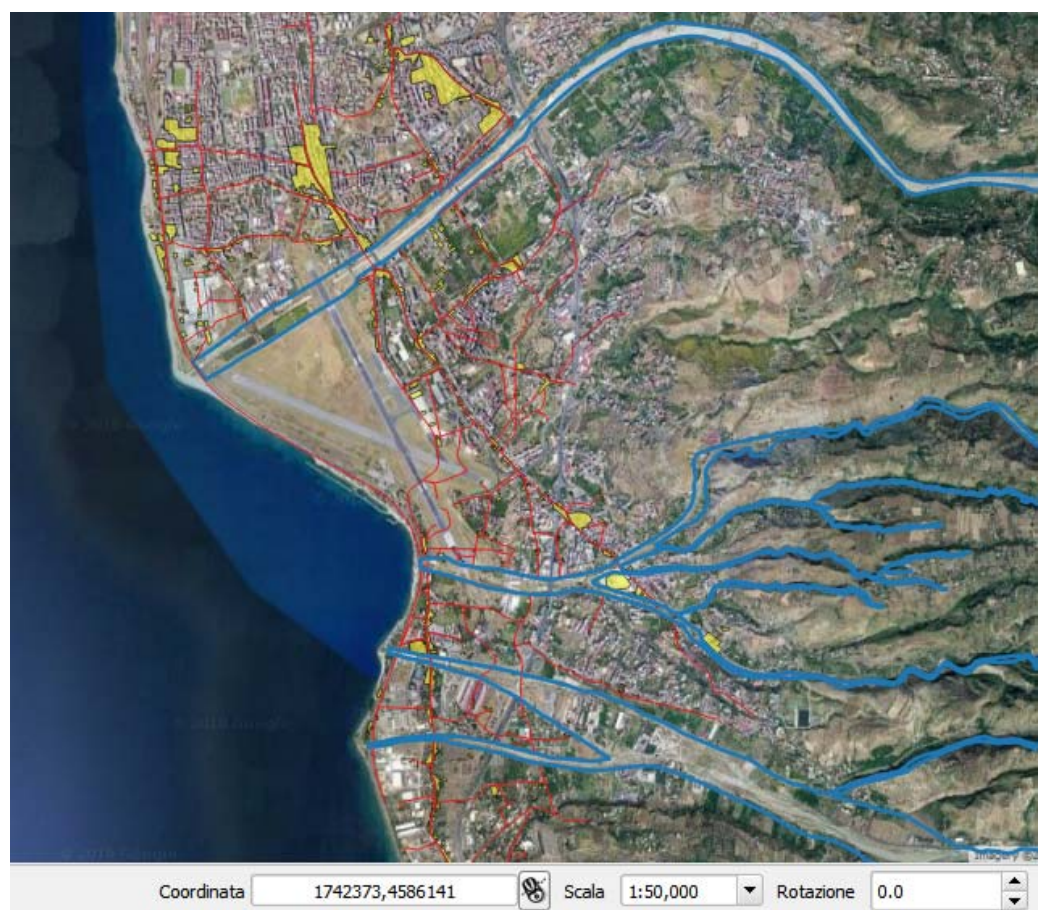

Figure 6: Shapefiles of rivers, roads and buildings of 1955, with the latest satellite imagery background. Legend: blue: rivers; red: roads; yellow: buildings.

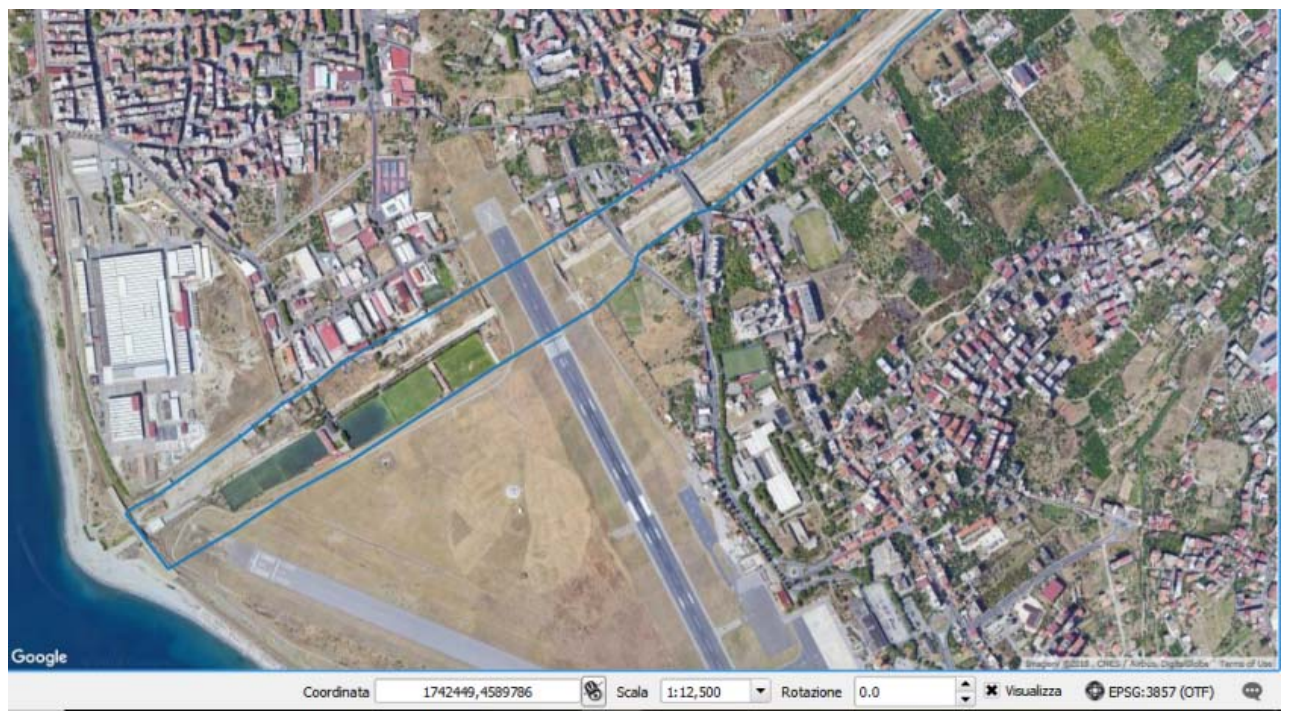

Figure 7: Shapefile of Sant'Agata river of 1955, in blue, with the latest satellite imagery background. 


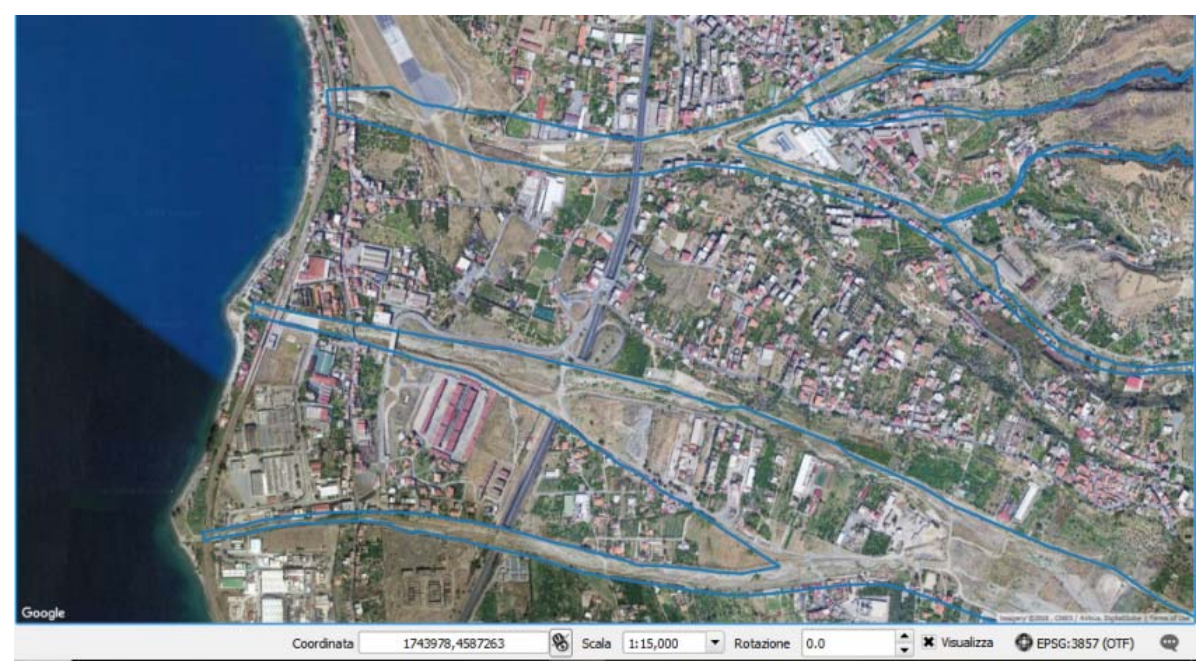

Figure 8: Shapefiles of Armo and Valanidi rivers of 1955, in blue, with the latest satellite imagery background.

\section{CONCLUSIONS}

The paper analyzes and describes the effects of anthropization process on some rivers in the southern area of the Reggio Calabria city, in particular the Sant'Agata, Armo and Valanidi rivers. The analysis was carried out using QGIS, through the comparison of cartography data of the last 60 years, which consists of aerophotogrammetry of 1955, provided by Italian Military Geographic Institute, and the latest satellite imagery provided by Google Earth Pro. Shapefiles were created to identify rivers, roads and buildings.

The analysis described in this paper showed how the study area has been strongly anthropized over the last 60 years. In fact, the 1955 aerophotogrammetry shows the presence of few buildings, most of which are distant from the rivers, which were characterized by very large beds.

At present, however, most of the areas adjacent to the rivers are very anthropized. In particular, the airport runway, built at the end of the $30 \mathrm{~s}$, has been extended both to the north, passing above the Sant'Agata river, and to the south, passing above the Armo river. Moreover, near the Sant'Agata river mouth, the riverbed was narrowed and channeled and a sports center was built inside the old river bed of 1955. Finally, with regard to the Valanidi river, a highway passes below the river itself through two tunnels.

The situation described above involves an increase in the flood events consequences and can alter the river dynamics contributing to increase the flooding risk. Therefore, the methodology described above is of interest in the fields of flood risk assessment and management and in the field of urban planning.

\section{REFERENCES}

[1] Trigila, A., Iadanza, C., Munafò, M. \& Marinosci, I., Population exposed to landslide and flood risk in Italy. Engineering Geology for Society and Territory, Springer International Publishing, pp. 843-848, 2015.

[2] ISPRA. Dissesto idrogeologico in Italia: pericolosità e indicatori di rischio. Rapporto n. 287, 2018. (in Italian). 
[3] Fiori, E., Comellas, A., Molini, L., Rebora, N., Siccardi, F., Gochis, D.J., Tanelli, S. \& Parodi, A., Analysis and hindcast simulations of an extreme rainfall event in the Mediterranean area: The Genoa 2011 case. Atmospheric Research, 138, pp. 13-29, 2014.

[4] Barbaro G., Petrucci O., Canale C., Foti G., Mancuso P. \& Puntorieri P., Contemporaneity of floods and storms. A case study of Metropolitan Area of Reggio Calabria in Southern Italy. Prooceedings of New Metropolitan Perspectives (NMP), Reggio Calabria, Italy, 2018.

[5] Scionti, F., Miguez, M.G., Barbaro, G., De Sousa, M.M., Foti, G. \& Canale, C., Integrated methodology for urban flood risk mitigation in Cittanova (Italy). Journal of Water Resources Planning and Management, 144(10), 2018.

[6] Destro, E., Amponsah, W., Nikolopoulos, E.I., Marchi, L., Marra, F., Zoccatelli, D. \& Borga, M., Coupled prediction of flash flood response and debris flow occurrence: Application on an alpine extreme flood event. Journal of Hydrology, 558, pp. 225237, 2018.

[7] De Franco, M., Minniti, M., Versaci, R., Foti. G., Canale, C. \& Puntorieri, P., Flash floods in urban areas: case studies in Reggio Calabria (Italy). Proceedings of $11^{\text {th }}$ International Conference on Urban Drainage Modeling, Palermo, Italy, 2018.

[8] Arena, F., Barbaro, G. \& Romolo, A., Return period of a sea storm with at least two waves higher than a fixed threshold. Mathematical Problems in Engineering, pp. 1-6, 2013.

[9] Boudet, L., Sabatier, F. \& Radakovitch, O., Modelling of sediment transport pattern in the mouth of the Rhone delta: Role of storm and flood events. Estuarine, Coastal and Shelf Science, 198, pp. 568-582, 2017.

[10] Komar, P.D., Coastal erosion-underlying factors and human impacts. Shore \& Beach, 68(1), pp. 3-16, 2000.

[11] Barbaro, G., Foti, G. \& Sicilia, C.L., Coastal erosion in the South of Italy. Disaster Advances, 7, pp. 37-42, 2014.

[12] Saghafian, B., Farazjoo, H., Bozorgy, B. \& Yazdandoost, F., Flood intensification due to changes in land use. Water Resources Management, 22(8), pp. 1051-1067, 2008.

[13] Chen, Y., Xu, Y. \& Yin, Y., Impacts of land use change scenarios on storm-runoff generation in Xitiaoxi basin, China. Quaternary International, 208(1), pp. 121-128, 2009.

[14] Campana, N.A. \& Tucci, C.E.M., Predicting floods from urban development scenarios: case study of the Dilúvio Basin, Porto Alegre, Brazil. Urban water, 3(1), pp. 113-124, 2001.

[15] Nirupama, N. \& Simonovic, S.P., Increase of flood risk due to urbanisation: a canadian example. Natural Hazards, 40(1), pp. 25-41, 2007.

[16] Huong, H.T.L. \& Pathirana, A., Urbanization and climate change impacts on future urban flooding in Can Tho city, Vietnam. Hydrological and Earth System Science, 17(1), pp. 379-394, 2013.

[17] Papagiannaki, K., Lagouvardos, K., Kotroni, V. \& Bezes, A., Flash flood occurrence and relation to the rainfall hazard in a highly urbanized area. Natural Hazards and Earth System Science, 15(8), pp. 1859-1871, 2015.

[18] Avinash, S., Flood related disasters: concerned to urban flooding in Bangalore, India. International Journal of Research in Engineering and Technology, pp. 76-83, 2016. 
[19] Singh, P., Sinha, V.S.P., Vijhani, A. \& Pahuja, N., Vulnerability assessment of urban road network from urban flood. International Journal of Disaster Risk Reduction, 28, pp. 237-250, 2018.

[20] Gaume, E. et al., A compilation of data on European flash floods. Journal of Hydrology, 367, pp. 70-78, 2009.

[21] Llasat, M.C., Llasat-Botija, M., Petrucci, O., Pasqua, A.A., Rosselló, J., Vinet, F. \& Boissier, L., Towards a database on societal impact of Mediterranean floods in the framework of the HYMEX project. Natural Hazards and Earth System Science, 13, pp. 1-14, 2013.

[22] Hall, J. et al., flood regime changes in Europe: a state of the art assessment. Hydrological and Earth System Science, 18, pp. 2735-2772, 2014.

[23] Zema, D.A., Bombino, G., Boix-Fayos, C., Tamburino, V., Zimbone, S.M. \& Fortugno, D., Evaluation and modeling of scouring and sedimentation around check dams in a Mediterranean torrent in Calabria, Italy. Journal of Soil and Water Conservation, 69(4), pp. 316-329, 2014.

[24] Fortugno, D., Boix-Fayos, C., Bombino, G., Denisi, P., Quinonero Rubio, J.M., Tamburino, V. \& Zema, D.A., Adjustments in channel morphology due to land-use changes and check dam installation in mountain torrents of Calabria (Southern Italy). Earth Surface Processes and Landforms, 42(14), pp. 2469-2483, 2017.

[25] Grimm, M., Jones, R.J.A. \& Montanarella, L., Soil Erosion Risk in Europe. European Soil Bureau Research Report, EUR 19939 EN. Office for Official Publications of the European Communities, Luxembourg, 2002.

[26] Grimm, M., Jones, R.J.A. \& Montanarella, L., Soil Erosion Risk in Italy: A Revised USLE Approach. European Soil Bureau Research Report No. 11, EUR 20677 EN. Office for Official Publications of the European Communities, Luxembourg, 2003.

[27] Perez-Arlucea, M., Mendez, G., Clemente, F., Nombela, M., Rubio, B. \& Filgueira, M., Hydrology, sediment yield, erosion and sedimentation rates in the estuarine environment of the Ria de Vigo, Galicia, Spain. Journal of Marine Systems, 54, pp. 209-226, 2005.

[28] Boak, E.H. \& Turner, I.L., Shoreline definition and detection: a review. Journal of Coastal Research, 21(4), pp. 688-703, 2005.

[29] Maiti, S. \& Bhattacharya, A.K., Shoreline change analysis and its application to prediction: A remote sensing and statistics based approach. Marine Geology, 257(14), pp. 11-23, 2009.

[30] Barbaro, G., Fiamma, V., Barrile, V., Foti, G. \& Ielo, G., Analysis of the shoreline changes of Reggio Calabria (Italy). International Journal of Civil Engineering and Technology, 8(10), pp. 1777-1791, 2017.

[31] Morton, R.A., Miller, T.A. \& Moore, L.J., National assessment of shoreline change: Part 1: Historical shoreline changes and associated coastal land loss along the US Gulf of Mexico. US Geological Survey Open-File Report 1043, 2004.

[32] Syvitski, J.P.M. \& Saito, Y., Morphodynamics of deltas under the influence of humans. Global and Planetary Change, 57(3-4), pp. 261-282, 2007.

[33] Manca, E., Pascucci, V., Deluca, M., Cossu, A. \& Andreucci, S., Shoreline evolution related to coastal development of a managed beach in Alghero, Sardinia, Italy. Ocean and Coastal Management, 85, pp. 65-76, 2013.

[34] Barbaro, G., A new expression for the direct calculation of the maximum wave force on vertical cylinders. Ocean Engineering, 34, pp. 1706-1710, 2007. 
[35] Barbaro G. \& Foti G., Shoreline behind a breakwater for wave energy absorption in Reggio Calabria: comparison between theoretical models and experimental data. Proceedings 2nd International Conference on Physical Coastal Processes, Management and Engineering (Naples, Italy), pp. 237-248, 2011.

[36] Barbaro, G., Saline Joniche: a predicted disaster. Disaster Advances, 6, pp. 1-3, 2013.

[37] Barbaro, G. \& Foti, G., Shoreline behind a breakwater: comparison between theoretical models and field measurements for the Reggio Calabria sea. Journal of Coastal Research, 29, pp. 216-224, 2013.

[38] Barbaro, G., Foti, G. \& Sicilia, C.L., Wave forces on upright breakwater, evaluation and case study. Disaster Advances, 6, pp. 90-95, 2013.

[39] Poeta, G., Conti, L., Malavasi, M., Battisti, C. \& Acosta, A.T.R., Beach litter occurrence in sandy littorals: The potential role of urban areas, rivers and beach users in central Italy. Estuarine, Coastal and Shelf Science, 181, pp. 231-237, 2016.

[40] Miduri, M., Foti G. \& Puntorieri P., Impact generated by Marina of Badolato (Italy) on adjacent coast. Proceeding of 13th International Congress on Coastal and Marine Sciences, Engineering, Management and Conservation (MEDCOAST), Mellieha (Malta), 2017.

[41] Barbaro, G., Estimating design wave for offshore structures in Italian waters. Proceedings of the Institution of Civil Engineering, Maritime Engineering, 164, pp. 115-125, 2011.

[42] Boccotti, P., Arena, F., Fiamma, V., Romolo, A. \& Barbaro, G., Estimation of mean spectral directions in random seas. Ocean Engineering, 38, pp. 509-518, 2011.

[43] Barbaro, G., Foti, G. \& Malara, G., Set-up due to random waves: influence of the directional spectrum. Proceedings 30th International Conference on Ocean, Offshore and Artic Engineering (Rotterdam, The Netherlands), 2011.

[44] Barbaro, G., Foti, G. \& Malara, G., Set-up due to random waves: influence of the directional spectrum. International Journal of Maritime Engineering, 155, pp. A105A115, 2013.

[45] Boccotti, P., Wave Mechanics and Wave Loads on Marine Structures, Elsevier BH: Oxford (UK), 2015.

[46] Barbaro, G., Foti, G., Mandaglio G., Mandaglio, M. \& Sicilia, C. L., Estimate of sediment transport capacity in the basin of the Fiumara Annunziata (RC). Rendiconti Online Società Geologica Italiana, 21(1), 696-697, 2012.

[47] Sicilia, C.L., Foti, G. \& Campolo, A., Protection and management of the Annunziata river mouth area (Italy). Journal of Air, Soil and Water Research, 6, pp. 107-113, 2013.

[48] Barbaro, G., Foti, G., Sicilia, C.L. \& Malara, G., A formula for the calculation of the longshore sediment transport including spectral effects. Journal of Coastal Research, 30, pp. 961-966, 2014.

[49] Tomasicchio, G.R., D’Alessandro, F., Barbaro, G., Musci, E. \& De Giosa, T.M., Longshore transport at shingle beaches: an independent verification of the general model. Coastal Engineering, 104, pp. 69-75, 2015.

[50] Borrello, M.M., Foti G. \& Puntorieri P., Shoreline evolution near the mouth of the Petrace River (Reggio Calabria, Italy). Proceedings of 9th International Conference on River Basin Management, Prague, Czech Republic, 2017.

[51] Xu, J.X., Sediment flux to the sea as influenced by changing human activities and precipitation: example of the Yellow River, China. Environmental Management, 31, pp. 328-341, 2003. 
[52] Geria, P.F., Foti, G. \& Puntorieri, P., Morphodynamic analysis of Tuccio River (South Calabria, Italy). Proceedings of 6th International Conference on Flood and Urban Water Management, A Coruna, Spain, 2018.

[53] Li, X., Zhou, Y., Zhang, L., Kuang, R., Shoreline change of Chongming Dongtan and response to river sediment load: a remote sensing assessment. Journal of Hydrology, 511, pp. 432-442, 2014.

[54] Yang, Z., Wang, T., Voisin, N. \& Copping, A., Estuarine response to river flow and sea-level rise under future climate change and human development. Estuarine, Coastal and Shelf Science, 156, pp. 19-30, 2015.

[55] Wang, H.J., Yang, Z.S., Saito, Y., Liu, J.P., Sun, X.X. \& Wang, Y., Stepwise decreases of the Huanghe (Yellow River) sediment load (1950-2005): impacts of climate change and human activities. Global and Planetary Change, 57, pp. 331-354, 2007.

[56] Yu, J., Fu, Y., Li, Y., Han, G., Wang, Y., Zhou, D., Sun, W., Gao, Y. \& Meixner, F.X., Effects of water discharge and sediment load on evolution of modern Yellow River Delta, China, over the period from 1976 to 2009. Biogeosciences, 8(9), pp. 2427-2435, 2011.

[57] Foti, G. \& Sicilia, C.L., Analysis, evaluation and innovative methodologies to prevent coastal erosion. Proceedings $3^{\text {rd }}$ International Conference on Physical Coastal Processes, Management and Engineering, Gran Canaria (Spain), 2013.

[58] Barbaro, G., Master Plan of solutions to mitigate the risk of coastal erosion in Calabria (Italy), a case study. Ocean \& Coastal Management, 132, pp. 24-35, 2016.

[59] Nucera, A., Foti, G., Canale, C., Puntorieri, P. \& Minniti, F., Coastal flooding: damage classification and case studies in Calabria (Italy). Proceedings of $11^{\text {th }}$ International Conference on Risk Analysis and Hazard Mitigation, Seville, Spain, 2018.

[60] Terranova, O., Antronico, L., Coscarelli, R. \& Iaquinta, P., Soil erosion risk scenarios in the Mediterranean environment using RUSLE and GIS: An application model for Calabria (southern Italy). Geomorphology, 112(3-4), pp. 228-245, 2009. 